\title{
Lethal and semi-lethal mutations in Holstein calves in Uruguay
}

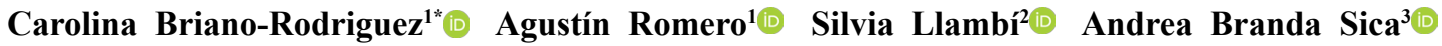 \\ María Teresa Federici Rodriguez ${ }^{3}$ (i) Federico Giannitti ${ }^{3}$ (D) \\ Rubén Dario Caffarena ${ }^{3}$ Carlos Omar Schild ${ }^{3}$ C \\ María Laura Casaux ${ }^{3}$ Fernando Dutra Quintela ${ }^{1}$ (D)
}

'DILAVE "Miguel C Rubino" (MGAP), Laboratorio Regional Este, 33000, Treinta y Tres, Uruguay. E-mail: cbriano@mgap.gub.uy. ${ }^{*}$ Corresponding autor.

${ }^{2}$ Facultad de Veterinaria, Universidad de la República (UDELAR), Uruguay.

${ }^{3}$ Instituto Nacional de Investigación Agropecuaria, INIA, Uruguay.

\begin{abstract}
Genetic disorders in Holstein cattle are a health problem that has grown worldwide in recent years, compromising the sustainability of modern dairy production. In Uruguay, Holstein-based milk production is one of the most important sectors of the country's economy, but high levels of inbreeding have decreased the breed's fertility in recent decades. This study investigated the presence and diffusion of lethal and semi-lethal alleles causing embryo death, abortions, fetal malformations, and neonatal diseases in Holstein calves. Using the GeneSeek ${ }^{\circledR}$ Genomic Profiler ${ }^{\mathrm{TM}}$ Bovine 50K BeadChip, we genotyped 383 calves (1-30 days-old) from 27 farms located in the main dairy region of Uruguay. Results showed a high prevalence of farms (85\%) and carrier calves (21\%), including one or more of the following semi-lethal or lethal alleles: Syndactylism (4.18\%), brachyspina (3.39\%), cholesterol deficiency haplotype (2.61\%), complex vertebral malformation (2.09\%), bovine leukocyte adhesion deficiency (1.04\%s), and Holstein haplotypes HH1 (4.44\%), HH3 (3.13\%), HH4 (1.04\%), and HH5 (0.26\%). Most of these alleles had not been recognized previously in Uruguay. We concluded that lethal and semi-lethal mutations are widespread in the Holstein breed in Uruguay. More studies are required to determine their impact on dairy cattle fertility.

Key words: bovine hereditary diseases, brachyspina, Holstein haplotypes, syndactyly, cholesterol deficiency, complex vertebral malformation, BLAD.
\end{abstract}

Mutações letais e semi-letais em bezerros da raça Holandesa no Uruguai

RESUMO: Os distúrbios genéticos nos bovinos da raça Holandesa são um problema de saúde que cresceu nos últimos anos a nível mundial, comprometendo a sustentabilidade da produção leiteira moderna. No Uruguai, a produção leiteira com base na raça Holstein é um dos setores mais importantes da economia do país, mas altos níveis de endogamia diminuíram a fertilidade da raça nas últimas décadas. O objetivo deste estudo foi investigar a presença e difusão de alelos letais e semi-letais causando morte de embriões, abortos, malformações fetais e doenças neonatais em bezerros da raça Holandesa. Usando o BeadChip Bovino 50K GeneSeek ${ }^{\circledR}$ Genomic Profiler ${ }^{\mathrm{TM}}$, genotipamos 383 bezerros (menos de um mês) de 27 fazendas localizadas na principal região leiteira do Uruguai. Os resultados mostraram uma alta prevalência de fazendas (85\%) e bezerros portadores (21\%), incluindo um ou mais dos seguintes alelos letais ou semi-letais: sindactilismo (4,18\%), braquipespina (3,39\%), haplótipo de deficiência de colesterol (2,61\%), malformação vertebral complexa (2,09\%), deficiência de adesão de leucócitos bovinos (1,04\% s) e haplótipos de Holstein HH1 (4,44\%), HH3 (3,13\%), HH4 (1,04\%) e HH5 (0,26\%). A maioria desses alelos não havia sido reconhecida anteriormente no país. Concluímos que as mutações letais e semi-letais são comuns na raça Holstein no Uruguai. Mais estudos são necessários para determinar seu impacto na fertilidade do gado leiteiro.

Palavras-chave: doenças hereditárias, braquipespina, haplótipos holandeses, deficiência de colesterol, BLAD.

\section{INTRODUCTION}

The global use of closely related HolsteinFriesian sires, mainly of North American origin, selected mainly for high milk yield and without taking into account reproductive traits or health indicators, has resulted in a worldwide inbreeding level and reduced the genetic diversity and survival traits of the breed. This loss of natural genetic resistance to diseases and the decreased fertility, vigor, and longevity of the breed, is compromising the sustainability of modern dairy production (RODRÍGUEZ-MARTÍNEZ et al., 2008). A large number of lethal and semi-lethal alleles have been reported worldwide in Holsteins in the last years as causes of embryo losses or fetal mortality, stillborn, and malformed or immunosuppressed calves, such as bovine leukocyte adhesion deficiency (BLAD) (KEHRLI et al., 1990; NAGAHATA, 2004), brachyspina (BY) (CHARLIER et al., 2012; AGERHOLM et al., 2010), deficiency of uridine 
monophosphate synthase (DUMPS) (SCHWENGER et. al.,1993), citrullinemia (CI) (DENNIS, et al. 1989), complex vertebral malformation (CVM) (THOMSEN, 2006), cholesterol deficiency haplotype (CDH) (KIPP, 2016), and several Holstein-Friesian haplotypes (VANRADEN et al., 2011; FRITZ et al., 2013), among many others. All these mutations are recessive and are expressed as a diseased phenotype only if both alleles are present, so the problem is only recognized when the gene frequency is high, and the allele is already fixed in the population.

Holstein-based milk production in Uruguay is one of the most important sectors of the country's economy, with dairy farms distributed throughout the country, mainly in the southeastern region. In recent decades, the national dairy stock has decreased mainly due to a drastic fall in pregnancy rate (20$30 \%$ ), increased calving-conception interval (from 131 to 175 days between 1997 and 2011) (MEIKLE et al., 2013), and high birth-to-weaning calf mortality, averaging 18\% (SCHILD et al., 2020). Another contributing factor could be the predominance of North American Holstein-Friesian genetics in the national herd (90\%), a breed in which most recessive mutations affecting reproductive efficiency and health traits have been discovered in recent years.

This aim research investigated the presence and diffusion of lethal and semi-lethal alleles that cause embryonic, fetal and perinatal/neonatal losses of Holstein calves in Uruguay.

\section{MATERIALS AND METHODS}

Three hundred eighty-three Holstein calves (1- to 30-day-old) from 27 farms located in the main dairy region of Uruguay were sampled in 2016 as part of a larger epidemiological study on neonatal diarrhea in dairy calves (SCHILD et al., 2020). Blood samples from diarrheic and non-diarrheic calves were collected from the jugular vein into Vacutainer ${ }^{\circledR}$ tubes $(4 \mathrm{ml})$ with Lithium Heparin 75 USP Units, transported to the laboratory, and stored at $4{ }^{\circ} \mathrm{C}$ until genomic DNA extraction. The extraction of DNA from whole-blood samples was carried out using a commercial DNA extraction kit (MagMAX $^{\mathrm{TM}}$-96DNA Multi-Sample Kit) and frozen at $-20{ }^{\circ} \mathrm{C}$ until analysis.

DNA samples were submitted to a commercial laboratory (Neogen GeneSeek, Lincoln, $\mathrm{NE}$ ) for genotyping using the custom GeneSeek Genomic Profiler -GGP- Bovine 50K BeadChip, which utilizes Illumina Infinium chemistry with approximately 50000 single nucleotide polymorphisms (SNPs) assayed per sample. The information generated by the $50 \mathrm{~K}$ BeadChip included most of the lethal and semi-lethal mutations recognized in beef and dairy cattle (https://genomics. neogen.com/pdf/ag311_ggp_bovine 50k_brochure. pdf). Only GenCall scores greater than 0.9 were used in calculations in order to ensure high-confidence genotypes. Allelic frequencies $(p=$ wild-type; $q=$ mutant) were analyzed using Pearson's Chi-square Hardy-Weinberg equilibrium (HWE) test calculator for biallelic markers, assuming that the observed genotypes (i.e. normal homozygotes and carrier heterozygotes) were correct (http://apps.biocompute. org.uk/hwe-mr-calc.html) (RODRIGUEZ et al., 2009). This calculator indicated the expected counts under HWE if gains or losses have occurred in one genotype group (e.g. loss of lethal homozygotes), either by technical o biological reasons, in addition to the conventional analysis which distributes gains/ losses across all three genotype groups (RODRIGUEZ et al., 2009). Data were analyzed in the statistical package MINITAB ${ }^{\circledR} 14.2$ (Minitab Inc., 2005) and results are given as means $\pm \mathrm{SD}$ or median with lower and upper quartiles (Q1-Q3). Standardized labeling for genetic traits and carrier coding recognized by the World Holstein Friesian Federation are used in this study (http://www.whff.info/documentation/ documents/GeneticTraitsandCarrierCodes.pdf).

\section{RESULTS AND DISCUSSION}

In total, 9 different mutations (lethal and semi-lethal) were found in this study. Genotype and allele frequencies are shown in Table 1. The global prevalence of farms with at least one mutation was $85 \%$ (23/27 farms), whereas the prevalence of calves carrying one or more mutations was $21.4 \%$ (83/383). These findings suggested that genetic diseases are widespread in the Holstein breed in Uruguay and are probably an important cause of prenatal and perinatal/neonatal losses, thus contributing to the low reproductive efficiency of the breed.

Among the 383 Holstein calves examined, there were 13 heterozygous for BY, 8 for CVM, 10 for $\mathrm{CDH}$, and 4 for BLAD. Syndactylism or Mulefoot (MF) was reported in 16 calves, 3 of which were homozygotes and 13 heterozygotes. Carriers of the following $4 \mathrm{HH}$ were found: $17 \mathrm{HH} 1,12 \mathrm{HH} 3$, four HH4, and 1 HH5 (Table 1). According to the HardyWeinberg test results, all mutant alleles (except for MF, $\mathrm{P}<0.05$ ) were in equilibrium ( $\mathrm{p}>0.05)$; although, the total number of animals analyzed is too low to suggest that these alleles are uniformly segregated in the studied population. Except for BLAD (LLAMBÍ 
Table 1 - Lethal and semi-lethal alleles detected in Holstein calves. Carrier prevalence, farm prevalence, median within-farm prevalence and estimated genotype and allele frequency are shown.

\begin{tabular}{|c|c|c|c|c|c|}
\hline $\mathrm{ALL} \mathrm{El}^{\mathrm{ea}}$ & $\begin{array}{l}\text { Carrier prevalence } \\
\text { (n) }\end{array}$ & $\begin{array}{l}\text { Farm prevalence } \\
\text { (n) }\end{array}$ & $\begin{array}{l}\text { Median within-farm } \\
\text { prevalence (Q1-Q3) }\end{array}$ & $\begin{array}{l}\text { Genotype } \\
\text { frequency }\end{array}$ & $\begin{array}{c}\text { Allele frequency } \\
\text { c }\end{array}$ \\
\hline & ( $\mathrm{N}=383$ calves $)$ & $(\mathrm{N}=27$ farms $)$ & & & (q) \\
\hline MF & $4.18 \%(16)$ & $22.2 \%(6)$ & $17.5 \%(10.9-27.0)$ & $0,03 / 0,01$ & 0.02 \\
\hline BY & $3.39 \%(13)$ & $25.9 \%(7)$ & $15.0 \%(5.8-25.0)$ & $0,03 / 0,00$ & 0.02 \\
\hline $\mathrm{CD}$ & $2.61 \%(10)$ & $14.8 \%(4)$ & $24.3 \%(8.8-25.0)$ & $0,03 / 0,00$ & 0.01 \\
\hline CVM & $2.09 \%(8)$ & $14.8 \%(4)$ & $5.7 \%(5.3-20.2)$ & $0,02 / 0,00$ & 0.01 \\
\hline BLAD & $1.04 \%(4)$ & $14.8 \%(4)$ & $5.4 \%(4.8-7.2)$ & $0,01 / 0,00$ & 0.01 \\
\hline HH 1 & $4.44 \%(17)$ & $29.6 \%(8)$ & $7.4 \%(5.5-14.0)$ & $0,04 / 0,00$ & 0.02 \\
\hline HH 3 & $3.13 \%(12)$ & $29.6 \%(8)$ & $6.8 \%(5.3-14.3)$ & $0,03 / 0,00$ & 0.02 \\
\hline $\mathrm{HH} 4$ & $1.04 \%(4)$ & $11.1 \%(4)$ & $7.7 \%(5.3-66.7)$ & $0,01 / 0,00$ & 0.01 \\
\hline HH 5 & $0.26 \%(1)$ & $3.7 \%(1)$ & $5.0 \%(--)$ & $0,003 / 0,00$ & 0.01 \\
\hline TOTAL & $82(21.4 \%)^{\mathrm{d}}$ & $23(85.2 \%)^{\mathrm{d}}$ & ---- & ---- & 0.12 \\
\hline
\end{tabular}

${ }^{\mathrm{a}} \mathrm{MF}=$ mule-foot, $\mathrm{BY}=$ brachyspine, $\mathrm{CD}=$ cholesterol deficiency, $\mathrm{CVM}=$ complex vertebral malformation, $\mathrm{BLAD}=$ bovine leukocyte adhesion deficiency, $\mathrm{HH}=$ Holstein haplotypes. ${ }^{\mathrm{b}}$ Genotype frequency: only heterozygous/homozygous recessive are shown. ${ }^{\mathrm{c}}$ Test performed by using the Hardy-Weinberg equilibrium calculator (http://www.oege.org/software/hwe-mr-calc.html). ${ }^{\mathrm{d}}$ Total refers to calves and farms with at least one allele present, so it does not match the sum of the individual alleles.

et al., 2003) and CVM (BRANDA-SICA et al., 2019), none of these mutations had previously been reported in Uruguay. DUMPS and CT, common in other countries, were not detected in the present study.

BLAD (Online Mendelian Inheritance in Animals - OMIA: 000595-9913) is a lethal autosomal recessive disorder that affects the Holstein cattle breed throughout the world. It is characterized by greatly reduced expression of heterodimeric b2 integrin adhesion molecules on leukocytes resulting in multiple defects in leukocyte function. Defective leukocyte adherence leads to inadequate mucosal immunity (NAGAHATA, 2004). Affected calves suffer serious and recurrent infections of body surfaces, such as stomatitis, pneumonia, enteritis, gingivitis, papillomatosis, dermatophytosis, or delayed scarring, usually dying during the neonatal period without having established a final diagnosis or being confused with other diseases (NAGAHATA, 2004). The mutation is not linked to any economically important trait in dairy cows (POWELL et al., 1994). The allele frequency of BLAD in the present study was $\mathrm{q}=0.01$, whereas carrier and farm frequency were $1.04 \%$ and $14.81 \%$, respectively. The frequency of BLAD carrier calves in this study was similar to that reported in one-year-old Uruguayan Holstein heifers in 2016 (0.5\%) (BRANDA-SICA et al., 2016), but much lower than that reported in adult cows and bulls in Uruguay in 2003 (7.2\%) (LLAMBÍ et al., 2003). It was also lower than that previously reported in adult Holsteins in other countries, such as Brazil (2.8\%), Japan (4\%), Turkey (4\%), the USA (4\%), and Poland (3\%) (NAGAHATA, 2004). Marker-assisted selection programs for decreasing BLAD carrier bulls used for artificial insemination have been enacted in many dairy countries, thus substantially reducing the frequency worldwide (NAGAHATA, 2004), including Uruguay.

CVM (OMIA: 001340-9913) is a recessively inherited disorder with onset during embryonic development leading to embryonic losses, abortion of affected fetuses mostly by day 260 of gestation, and perinatal death associated with shortening of the cervicothoracic vertebral column, arthrogryposis, hemivertebrae, scoliosis and in some cases also cardiac anomalies and transposition of the aorta (AGERHOLM, 2007). The pathological diagnosis of CVM can be difficult and requires detailed skeletal necropsy of affected fetuses or newborns. Genomic analysis has identified a point mutation in the gene SLC35A3, a nucleotide sugar transporter essential for development of the axial skeleton, thus leading to vertebral malformations (THOMSEN et al., 2006). The allelic frequency of 
CVM in our study was 0.01 , similar to previously reported values in several countries (MEYDAN et al., 2010; THOMSEN et al., 2006), but lower than reported for Holstein cows from the Milk Genomic DNA Bank of Uruguay $(q=0.032)$ (BRANDASICA et al., 2019). Carrier prevalence $(2.09 \%, 8 / 383$ CMV-carrier calves), farm prevalence (14.8\%, 4/27 farms with at least one CMV-carrier calf), and the relatively high frequency of the mutation $(25 \%, 5$ out of 20 calves) on one of the dairy farms sampled in the present study suggested that CVM is probably widespread on Uruguayan dairy farms. This may be due to the significant use of the sire Carlin-M Ivanhoe Bell (US1667366) in the country (KELLY et al., 2012), one of the great production bulls of the 1980s, which was heavily used worldwide because his daughters had high milk production (AGERHOLM, 2007). Programs for screening and control of CVM in the active sire population is possible, but control of the disease is complicated because the mutation is linked to milk production, which is a major economic factor on dairy farms.

BY (OMIA: 000151-3319) is characterized by stillborn calves with a very low body weight, intrauterine growth retardation, and severe vertebral malformations causing shortening of the spine, with long and thin limbs, and inferior brachygnathism. Embryonic mortality is rather common, which has a large, negative impact on herd fertility (AGERHOLM et al., 2010). It is caused by a $3.3-\mathrm{kb}$ deletion in the bovine Fanconi anemia complementation group I (FANCI) gene on chromosome 21, which is involved in DNA cross-link repair and apical ectodermal ridge development (CHARLIER et al., 2012). In the present study, the BY-allele frequency was $\mathrm{q}=0.02$, with 13 carrier calves $(3.4 \%)$ detected on 8 different farms $(8 / 27=25.9 \%)$ and a median carrier frequency on affected farms of $15 \%(\mathrm{Q} 1-\mathrm{Q} 3=5.9-25 \%)$, showing that the mutation is highly prevalent in dairy cattle in Uruguay. The mutation has been traced back to the elite US Holstein sire, Sweet Haven Tradition, a descendant of which, Rothrock Tradition Leadman, was widely used in Uruguay (RAVAGNOLO et al., 2004). Although, the elimination of all BY-carrier bulls would be the most efficient method to control this genetic disorder, many carrier bulls are still listed commercially for artificial insemination. Analysis of pedigree catalogs revealed that $7.4 \%$ of the HolsteinFriesian sires used in Uruguay before 2014 were BY-carriers and mostly imported from the USA and Canada (ARTIGAS et al., 2020).

Syndactyly, Syndactylism, or MF (OMIA: 000963-9913) is a malformation of the distal limbs characterized by complete or partial fusion of digits III and IV (LEIPOLD et al., 1973). The mode of inheritance is autosomal recessive with incomplete penetrance and variable expression, as the number of affected limbs and degree of digital fusion varies, with some animals appearing inclusively clinically normal (LEIPOLD et al., 1973). Syndactyly per se is not lethal, but affected animals are usually culled due to their reduced mobility, low weight gain, serious heat adaptation problems, and frequent heatstroke during hot summer weather (LEIPOLD et al., 1973). Molecular studies have identified a number of different causal, co-segregating mutations in the lowdensity lipoprotein-receptor-related protein 4 gene (LRP4), which is involved in organogenesis and limb bud development (DRÖGEMÜLLER et al., 2007). In the present study, the MF-allele frequency was $\mathrm{q}$ $=0.02$, with $16 \mathrm{MF}$-carrier calves $(4.2 \%)$ detected on 6 different farms $(22.2 \%)$ and a median carrier frequency on affected farms of $17.5 \%$ (Q1-Q3 = $12.6-23.7 \%$ ), showing that MF mutation is highly prevalent in dairy cattle in Uruguay. Three of the 16 carrier calves were recessive homozygotes and apparently normal, but due to a lack of more precise clinical information, such as x-rays, we were unable to confirm if the homozygous calves had any degree of bone fusion. The difference between expected and observed values for MF genotype counts was highly significant (Chi-squared 34.1, p <0.001), showing strong deviations of the Hardy-Weinberg equilibrium. This change in gene frequency may be explained by the selective advantage of normal heterozygotes, which are significantly superior for the production of milk and butterfat compared to non-carrier animals (LEIPOLD, 1973). Thus, the high frequency of syndactyly in the Holstein-Friesian population in Uruguay reveals that superior carrier animals, especially bulls, are still selected in dairy breeding. Eradication of this disorder requires more precise detection methods (DRÖGEMÜLLER et al., 2007).

CD (OMIA 001965-9913) is a newly recognized autosomal co-dominant genetic disorder described in Holstein cattle in several countries, which is reported here for the first time in Uruguay. The analysis of the pedigree of calves, known to have died from this condition, led to the Canadian Holstein sire Maughlin Storm, born in 1991 (KIPP et al., 2016). The condition occurs due to a mutation in the apolipoprotein B (APOB) gene, which is necessary for lipid metabolism, steroid biosynthesis, and cholesterol absorption from the small intestine (MENZI et al., 2016). Some heterozygotes calves 
have reduced blood cholesterol, whereas in recessive homozygotes, blood cholesterol level and triglyceride concentrations are practically zero (KIPP et al., 2016), indicating that $\mathrm{CD}$ represents an incomplete dominant metabolic disease with incomplete penetrance in heterozygotes (HÄFLIGER et al., 2019). The disease is normally confused with other types of neonatal diarrheas. Affected calves have severe unresponsive diarrhea, hypocholesterolemia, stunted growth, and generally die within the first few weeks or months of life (KIPP et al., 2016). In Germany, the prevalence of carriers is estimated at $12.5 \%$ and it is calculated that around 3400 homozygotes Holstein calves are born each year for this haplotype leading to annual economic losses of approximate 1.3 million Euros (KIPP et al., 2016). In the present study, the CDallele frequency was $\mathrm{q}=0.01$, with $10 \mathrm{CD}$-carrier calves $(2.61 \%)$ detected on four different farms $(14.8 \%)$, with a median carrier frequency of $24.3 \%$ per farm (Q1-Q3 = 18.6-25.0\%). Six out of $10 \mathrm{CD}$ carrier calves had neonatal diarrhea, suggesting that the CD mutation is likely contributing to this highly prevalent multifactorial syndrome in Uruguay. None of the other mutations were found to be associated with this syndrome. Cholesterol deficiency should be included in the differential diagnosis of neonatal diarrhea in Holstein calves and, as the CD haplotype is a genetic background for neonatal calf diarrhea, it should be included in future breeding strategies.

Holstein Haplotypes $(\mathrm{HH})$ are recessive lethal mutations responsible for a large number of embryonic and fetal losses impacting reproductive efficiency of breeds across the world (VANRADEN et al., 2011). Many were discovered over the past decade because, as no homozygote embryos survive, they never occur in homozygosis among postnatal animal, a scenario that is highly unlikely based on population probabilities (FRITZ et al., 2013; VANRADEN et al., 2011). The present study highlighted the presence of the following four HH: HH1 (OMIA: 000001-9913), HH3 (OMIA: 001824-9913), HH4 (OMIA: 0018269913), and HH5 (OMIA: 001941-9913). In our research, 15 of the 27 dairy farms investigated (67\%) had at least one of the $\mathrm{HH}$, whereas on 2 of the farms there were 3 different haplotype types, showing a widespread distribution of these important mutations on Uruguayan dairy farms.

Haplotypes HH1 and HH3 were the most prevalent reported in our study, suggesting their importance as causes of embryonic and fetal losses in Holstein cattle in Uruguay. Both mutations are also associated with a significantly lower reproductive efficiency in Holsteins worldwide (ADAMS et al.,
2016; DAETWYLER et al., 2014). In the present study, HH1 frequency was $\mathrm{q}=0.02$, with $17 \mathrm{HH} 1$ carrier calves (4.4\%) detected on 8 farms $(29.6 \%)$, with a median carrier frequency per farm of $7.2 \%$ $(\mathrm{Q} 1-\mathrm{Q} 3=5.5-14.1 \%)$. This haplotype is a nonsense mutation in apoptosis peptide activating factor 1 (APAF1), which is crucial in embryonic development and was traced to the elite US bulls Pawnee Farm Arlinda Chief, born in 1962, and his son Walkway Chief Mark, born in 1978 (ADAMS et al., 2016), both much used in Uruguay (RAVAGNOLO et al., 2004). It is believed that currently $14 \%$ of the Holstein genome in the US comes from these bulls and it is estimated that $\mathrm{HH} 1$ has caused more than 525,000 spontaneous abortions over the past 35 years (ADAMS et al., 2016). Regarding haplotype HH3, the allele frequency was $\mathrm{q}=0.02$, with $13 \mathrm{HH}$ carrier calves $(3.1 \%)$ detected on 8 farms $(29.6 \%)$, and a median carrier frequency of $8.8 \%$ per farm $(\mathrm{Q} 1-\mathrm{Q} 3=5.4-15.1 \%)$. It is caused by mutation ( $\mathrm{T}$ $\rightarrow \mathrm{C}$ ) in the SMC2 gene (Structural Maintenance of Chromosomes 2) located on chromosome 8, which has an essential role in DNA repair, chromosomal condensation, and segregation during rapid mitotic events, leading to embryonic losses before 60 days; although, the stillbirth rate is also slightly higher than normal (FRITZ et al., 2013). The founding allele was traced to the US sires Glendell Arlinda Chief and Gray View Skyliner (FRITZ et al., 2013).

Haplotypes HH4 and HH5 were detected in the present study but in a much lower prevalence compared with $\mathrm{HH} 1$ and $\mathrm{HH} 3$. The calculated allele frequency of $\mathrm{HH} 4$ was $\mathrm{q}=0.01$, with four carrier calves $(1.0 \%)$ detected on three farms $(11.1 \%)$ and a median carrier frequency of $7.7 \%$ per farm (Q1$\mathrm{Q} 3=5.3-66.7 \%)$. Only one HH5-carrier calf was detected $(0.3 \%)$. Both haplotypes are associated with infertility due to embryonic death in the first month of gestation. Haplotype HH4 is a missense mutation $\mathrm{A} \rightarrow \mathrm{C}$ in the glycinamide ribonucleotide GART gene (formyltransferase), which plays an important role in the purine biosynthesis pathway and causes the death of conceptuses soon after fertilization (FRITZ et al., 2013), while HH5 is a deletion that affects TFB1M (mitochondrial transcription factor B1), which affects mitochondrial function and causes embryonic mortality before 60 days of gestation (SCHÜTZ et al., 2016). The carrier frequencies in this study were much lower than those reported for HH4 in France (3.6\%) (FRITZ et al., 2013) and for HH5 in Germany (5.5\%) (SCHÜTZ et al., 2016), perhaps because genetic lines used in Uruguay are mostly from the US. 


\section{CONCLUSION}

This study demonstrated the presence of 9 different lethal or semi-lethal mutations in the Holstein-Friesian breed in Uruguay. The combined high prevalence of MF, BLAD, CVM, BY, HCD, $\mathrm{HH} 1, \mathrm{HH} 3, \mathrm{HH} 4$, and $\mathrm{HH} 5$ (21.4\% of sampled animals carried one or more recessive alleles), mostly causing embryonic and fetal losses, suggests a significant genetic background for explaining decreasing Holstein reproductive efficiency in Uruguay. Assuming random mating, a global allele frequency of $q=0.12$ and an annual served population of 420,000 Holstein cows and heifers, it can be estimated that about 6000 prenatal losses are due to homozygous lethal mutations. Therefore, the fertility impact of recessive alleles in the Holstein breed in Uruguay is huge.

Genomic monitoring of carrier animals and pedigree analyses to identify possible common ancestor(s) among the carrier calves for each disease are necessary to avoid dispersion of lethal and semilethal alleles in the Holstein population, determine their impact on dairy cattle fertility, and reduce economic losses to dairy farming.

\section{ACKNOWLEDGEMENTS}

This research was funded by grant N-15156 of the Uruguayan Instituto Nacional de Investigación Agropecuaria (INIA).

\section{BIOETHICS AND BIOSSECURITY COMMITTEE APPROVAL}

No ethical approval was required for this study (INIA, CEUA, protocol \# 20199). Animal owners consented to the diagnostic work-up for research purposes and the inclusion of their animals in this study.

\section{DECLARATION OF CONFLICT OF INTEREST}

The authors declare no conflict of interest. The founding sponsors had no role in the design of the study; in the collection, analyses, or interpretation of data; in the writing of the manuscript, and in the decision to publish the results.

\section{AUTHORS' CONTRIBUTIONS}

1. Study conception and design, 2. Data acquisition, 3 . Data analysis, 4. Results discussion, 5. Writing of the manuscript, 6. Approval of the final version of the manuscript.

C. Briano: 1, 2, 3, 4, 5 \& 6, F. Dutra: 1, 3, 4, 5 \& 6, A. Romero, A Branda-Sica and M. Federici: 4\&6, S. Llambí: 3, 4\&6, F. Giannitti, R. Caffarena, C. Schild and M. Casaux: $2 \& 6$.

\section{REFERENCES}

ADAMS, H.A. et al. Identification of a nonsense mutation in $A P A F 1$ that is likely causal for a decrease in reproductive efficiency in Holstein dairy cattle. Journal of Dairy Science, v.99, p.66936701, 2016. Available from: <https://www.journalofdairyscience. org/article/S0022-0302(16)30352-6/fulltext>. Accessed: Jun. 16, 2020. doi: 10.3168/jds.2015-10517.

AGERHOLM, J.S. Complex vertebral malformation syndrome in Holstein cattle: the story so far. Acta Veterinaria Scandinavica, v.49, S5, 2007. Available from: <https://actavetscand. biomedcentral.com/articles/10.1186/1751-0147-49-S1-S5>. Accessed: Jun. 23: doi: 10.1186/1751-0147-49-S1-S5.

AGERHOLM, J.S. et al. First confirmed case of the bovine brachyspina syndrome in Canada. The Canadian Veterinary Journal, v.51, n.12, p.1349-1350, 2010. Available from: <https:// www.ncbi.nlm.nih.gov/pmc/articles/PMC2978986 /\#b3cvj_12_1349>. Accessed: Jun. 16, 2020.

ARTIGAS, R. et al. Identificación por catálogo y detección molecular de bovinos Holando portadores de braquiespina en Uruguay. Revista FAVE - Sección Ciencias Veterinarias, 19, pp. 50-54, 2020. Available from: $<$ https://doi.org/10.14409/favecv. v19i2.9523>. Accessed: Jun. 16, 2020.

BRANDA-SICA, A. et al. Identificación de terneras Holando portadoras de BLAD y Citrulinemia en la región Este de Uruguay por PCR-RFLP y secuenciación. Veterinaria (Montevideo), v.52, n.202, p.3, 2016. Available from: $<$ http://www.scielo.edu.uy/scielo. php?script $=$ sci_arttext\&pid=S1688-48092016000200003\&lng=es $\&$ nrm $=$ iso $>$. Accessed: 16 jun. 2020

BRANDA-SICA, A. Identification of Holstein cow carriers of complex vertebral malformation by high resolution melting curves (HRM). Archives of Veterinary Science, v.24, n.4, pp. 62-70, 2019.

CHARLIER, C. et al. A Deletion in the Bovine FANCI Gene Compromises Fertility by Causing Fetal Death and Brachyspina. PLoS One 7(8): e43085, 2012. <https://doi.org/10.1371/journal. pone. $0043085>$. Accessed: Jul. 27, 2020.

DAETWYLER, H.D., et al. Whole-genome sequencing of 234 bulls facilitates mapping of monogenic and complex traits in cattle. Nature Genetics, 46(8), pp.858-865, 2014. Available from: $<$ https://doi.org/10.1038/ng.3034>. Accessed: Jun. 16, 2020.

DENNIS, J.A. et al. Molecular definition of bovine argininosuccinate synthetase deficiency. Proceedings of the National Academy of Sciences, 86(20), pp.7947-7951, 1989. Available from: <https:// doi.org/10.1073/pnas.86.20.7947>. Accessed: Jun. 16, 2020.

DRÖGEMÜLLER, C. et al. Congenital syndactyly in cattle: four novel mutations in the low-density lipoprotein receptor-related protein 4 gene (lrp4). BMC Genetics, v.85, 2007. Available from: $<$ https://doi.org/10.1186/1471-2156-8-5>. Accessed: Jun. 16, 2020 .

FRITZ, S. et al. Detection of haplotypes associated with prenatal death in dairy cattle and identification of deleterious mutations in GART, SHBG and SLC37A2. PLoS One, 8(6), e65550, 2013. Available from: <https://doi.org/10.1371/journal.pone.0065550>. Accessed: Jun. 16, 2020. doi: 10.1371/journal.pone. 0065550. 
HÄFLIGER, I.M. et al. APOB-associated cholesterol deficiency in Holstein cattle is not a simple recessive disease. Animal Genetics, 50(4), p.372-375, 2019. Available from: $<$ https://doi. org/10.1111/age.12801>. Accessed: Jun. 16, 2020.

KEHRLI, M.E. et al. Molecular definition of the bovine granulocytopathy syndrome: identification of deficiency of the Mac1 (CD11b/CD18) glycoprotein. American Journal of Veterinary Research 51, p.1826-1836, 1990. Available from: <https://www. researchgate.net/profile/Marcus_Kehrli/publication/21176625 Molecular definition of the bovine granulocytopathy syndrome_Identification_of_deficiency_of_the_Mac-1_ CD11bCD18_glycoprotein/links/57fe356b08ae7275640141b4. pdf $>$. Accessed: Jun. 16, 2020.

KELLY, L., et al. Diagnóstico molecular de enfermedades hereditarias bovinas en el Uruguay. Veterinaria (Montevideo), v.48, n.188, p.3-11. 2012. Available from: <http://www. revistasmvu.com.uy/index.php/smvu/article/view/208>. Accessed: Jun. 16, 2020.

KIPP, S., et al. Identification of a haplotype associated with cholesterol deficiency and increased juvenile mortality in Holstein cattle. Journal of Dairy Science, v.99, n.11, p.8915-8931, 2016. Available from: <https://doi.org/10.3168/jds.2016-11118>. Accessed: Jun. 16, 2020.

LEIPOLD, H.W. et al. Syndactyly in cattle. Veterinary Bulletin, 43:399-403, 1973.

LLAMBÍ, S., et al. Frequencia da deficiencia na adesão leucocitaria em uma população de bovinos da raça Holandesa, no Uruguai. ARS Veterinaria, v.19, p.52-56, 2003. Available from: $<$ http://www.arsveterinaria.org.br/arquivo/2003/v.19,\%20n.1,\%20 2003/52-56.pdf>. Accessed: Jun. 16, 2020.

MEIKLE, A., et al. Avances en el conocimiento de la vaca lechera durante el período de transición en Uruguay: un enfoque multidisciplinario. Agrociencias Uruguay, v.17, n.1, p.141-152, 2013. Available from: < http://www.ainfo.inia.uy/digital/bitstream/ item/4897/1/MEIKLE-et-al.-2013-767-1878-1-SM.pdforhttp:// www.scielo.edu.uy/pdf/agro/v17n1/v17n1a17.pdf $>$. Accessed: Mar. 18, 2020

MENZI, F., et al. A transposable element insertion in APOB causes cholesterol deficiency in Holstein cattle. Animal Genetics, 47(2):253-257, 2016. Available from: https://doi.org/10.1111/ age.12410. Accessed: Mar. 18, 2020.

MEYDAN, H., et al. Screening for bovine leukocyte adhesión deficiency, deficiency of uridine monophosphate synthase, complex vertebral malformation, bovine citrullinaemia, and factor XI deficiency in Holstein cows reared in Turkey. Acta Veterinaria Scandinavica, v.52, n.1, p.56, 2010. Available from: $<$ https://doi. org/10.1186/1751-0147-52-56>. Accessed: Mar. 23, 2020. doi: $10.1186 / 1751-0147-52-56$.

NAGAHATA, H. Bovine leukocyte adhesion deficiency (BLAD): A review. The Journal of Veterinary Medical Science, v.66, n.12, p.1475-1482, 2004. Available from: <https://doi.org/10.1292/ jvms.66.1475>. Accessed: May. 23, 2020. doi: 10.1292/ jvms.66.1475.

OMIA (Online Mendelian Inheritance in Animals). Faculty of Veterinary Science, University of Sydney.2020. [İnternet]. [Last updated: 12 Jun 2020, available from: <http://omia.org/home/>.] Accessed: Jun. 12, 2020.

POWELL, R.L., et al. Relationship of bovine leukocyte adhesion deficiency with genetic merit for performance traits. Journal of Dairy Science, v. 79, p. 895-899, 1994. Available from: <https:// doi.org/10.3168/jds.S0022-0302(96)76438-X>. Accessed: Jun. 23,2020

RAVAGNOLO, O., et al. Evaluación Genética Nacional Raza Holando 2004. Available from: <http://www.inia.org.uy/ publicaciones/documentos/1b/pol/2004/cata_hola_04.pdf $>$. Accessed: Jun. 11, 2020.

RODRIGUEZ-MARTINEZ, H., et al. Reproductive performance in high-producing dairy cows: can we sustain it under current practice. IVIS Reviews in veterinary Medicine, v.1, n.108, p.123, 2008. Available from: <http://urn.kb.se/resolve?urn=urn:nbn:s e:slu:epsilon-1-164>. Accessed: Jun. 11, 2020.

RODRIGUEZ, S., et al. Hardy-Weinberg equilibrium testing of biological ascertainment for Mendelian randomization studies. American Journal of Epidemiology, 169, n.4, p.505-514. 2009. Available from: $<$ https://doi.org/10.1093/aje/kwn359 > . Accessed: Apr. 15, 2019.

SCHILD C. et al. A survey of management practices that influence calf welfare and an estimation of the annual calf mortality risk in pastured dairy herds in Uruguay. Journal of Dairy Science, 2020, in press.

SCHÜTZ, E., et al. The Holstein Friesian lethal haplotype 5 (HH5) Results from a complete deletion of TBF1M and cholesterol deficiency (CDH) from an ERV-(LTR) Insertion into the Coding Region of APOB. PLoS One, v.11, n.4, e0154602, 2016. Available from: <https://doi.org/10.1371/journal.pone.0154602>. Accessed: Jun. 11, 2020.

SCHWENGER, B. et al. DUMPS cattle carry a point mutation in the uridine monophosphate synthase gene. Genomics,. 16(1), pp.241-244, 1993. Available from: <https://doi.org/10.1006/ geno.1993.1165>. Accessed: Jun. 11, 2020.

THOMSEN, B., et al. A missense mutation in the bovine SLC35A3 gene, encoding a UDP-N-acetylglucosamine transporter, causes complex vertebral malformation. Genome Research, v.16, n.1, p.97-105, 2006. Available from: <https://doi.org/10.1101/ gr.3690506>. Accessed: Jun. 11, 2020. doi:10.1101/gr.3690506.

VANRADEN, P.M., et al. Harmful recessive effects on fertility detected by absence of homozygous haplotypes. Journal of Dairy Science, v. 94, p.6153-6161, 2011. Available from: <https://doi. org/10 .3168/jds.2011-4624>. Accessed: Jun. 11, 2020. 